\title{
Fabrication of More Oxygen Vacancies and Depression of Encapsulation for Superior Catalysis in Water-Gas Shift Reaction
}

Qijun Pei, ${ }^{1}$ Guanghao Qiu ${ }^{1,2}$, Yang Yu, ${ }^{1}$ Jintao Wang, ${ }^{1,2}$ Khai Chen Tan, ${ }^{1,2}$ Jianping Guo, ${ }^{1}$ Lin Liu, ${ }^{1}$ Hujun Cao, ${ }^{1}$ Teng He, ${ }^{1, *}$ and Ping Chen ${ }^{1,3}$

${ }^{1}$ Dalian Institute of Chemical Physics, Chinese Academy of Sciences, Dalian 116023, China.

${ }^{2}$ University of Chinese Academy of Sciences, Beijing 100049, China.

${ }^{3}$ State Key Laboratory of Catalysis, Dalian Institute of Chemical Physics, Chinese Academy of Sciences, Dalian 116023, China.

*Corresponding author's E-mails: heteng@dicp.ac.cn 


\section{EXPERIMENTAL METHODS}

Materials and catalyst preparation. Nano $\mathrm{TiO}_{2}$ (anatase and rutile, 99.8\%, Aladdin) and $\mathrm{TiO}_{2}\left(\mathrm{P} 25\right.$, Degussa) were commercially available. $\mathrm{Ni}\left(\mathrm{NO}_{3}\right)_{2} \cdot 6 \mathrm{H}_{2} \mathrm{O}, \mathrm{NaOH}$ and $\mathrm{KOH}$ were purchased from Tianjin Kermel Reagent Company. 3\% $\mathrm{Ni}^{-} \mathrm{TiO}_{2}$ was prepared by impregnation method. Typically, $150 \mathrm{mg} \mathrm{Ni}\left(\mathrm{NO}_{3}\right)_{2} \cdot 6 \mathrm{H}_{2} \mathrm{O}$ was dissolved in deionized water, then $970 \mathrm{mg}$ anatase $\mathrm{TiO}_{2}$ powder was added into the $\mathrm{Ni}\left(\mathrm{NO}_{3}\right)_{2}$ solution. The suspension was stirred for $6 \mathrm{~h}$ at $50{ }^{\circ} \mathrm{C}$ in an oil bath, then dried for $3 \mathrm{~h}$ at $100{ }^{\circ} \mathrm{C}$ in an oven, finally calcined for $4 \mathrm{~h}$ in air at $400{ }^{\circ} \mathrm{C}$ in a muffle furnace. The calcined sample was reduced at $350{ }^{\circ} \mathrm{C}$ in hydrogen flow for $2 \mathrm{~h}$ before usage, and the catalyst was denoted as $\mathrm{Ni} / \mathrm{TiO}_{2}$. Typically, the alkali-doped catalyst was prepared by impregnating the calcined $\mathrm{Ni} / \mathrm{TiO}_{2}$ sample with a certain amount of alkali hydroxide. The catalyst was denoted as $\mathrm{Ni} / \mathrm{TiO}_{2}$-alkali after it was reduced at $350{ }^{\circ} \mathrm{C}$ in hydrogen flow for $2 \mathrm{~h}$. The brief process of catalyst preparation is shown in Figure S16.

Catalytic performance evaluations. WGS performance evaluations were measured in a fixed-bed quartz reactor at atmospheric pressure, the products were quantified by an online GC-8A Shimadzu gas chromatograph. The calcined catalysts were made into particles of 40-60 mesh. Typically, $150 \mathrm{mg}$ catalyst was loaded into the quartz reactor and was reduced in hydrogen gas flow at $350{ }^{\circ} \mathrm{C}$ for $2 \mathrm{~h}$. The feed gas is consisted of $5 \% \mathrm{CO}, 20 \% \mathrm{H}_{2} \mathrm{O}$ and $75 \% \mathrm{He}$, and the water was injected into a preheater with a calibrated double-plunger pump (Elite P230), where it was vaporized and mixed with $\mathrm{CO}$ and He. The feed gas flow was $50 \mathrm{~mL} / \mathrm{min}$, and a weight hourly space velocity (WHSV) was maintained at $20000 \mathrm{~mL} \cdot \mathrm{g}_{\mathrm{cat}} \cdot \mathrm{h}^{-1}$. The composition of outlet gas was analyzed by an online GC-8A Shimadzu gas chromatograph with TCD detector. The $\mathrm{CO}$ conversion and $\mathrm{CH}_{4}$ yield were calculated by the equations below:

$$
\begin{aligned}
X_{\mathrm{CO}} & =\frac{\left[\mathrm{CO}_{2}\right]_{\text {out }}+\left[\mathrm{CH}_{4}\right]_{\text {out }}}{[\mathrm{CO}]_{\text {out }}+\left[\mathrm{CO}_{2}\right]_{\text {out }}+\left[\mathrm{CH}_{4}\right]_{\text {out }}} \\
Y_{\mathrm{CH}_{4}} & =\frac{\left[\mathrm{CH}_{4}\right]_{\text {out }}}{[\mathrm{CO}]_{\text {out }}+\left[\mathrm{CO}_{2}\right]_{\text {out }}+\left[\mathrm{CH}_{4}\right]_{\text {out }}}
\end{aligned}
$$

Characterizations. XRD measurements were carried out on a PANalytical X'pert 
diffractometer with $\mathrm{Cu} K \alpha$ radiation $(\lambda=0.154 \mathrm{~nm})$ at a setting of $40 \mathrm{kV}$ and $40 \mathrm{~mA}$. HRETEM was performed on a JEOL 2000EX electronic microscope operating at 120 $\mathrm{kV}$. The Ni loadings of the prepared catalysts were determined by inductively coupled plasma-optical emission spectrometry (ICP-OES, optima 7300 DV, PerkinElmer). The measured $\mathrm{Ni}$ loadings for $\mathrm{Ni} / \mathrm{TiO}_{2}(\mathrm{~A})$ and $\mathrm{Ni} / \mathrm{TiO}_{2}(\mathrm{~A})-\mathrm{Na}$ are 2.2 and 2.1 wt.\%, respectively. The XPS were measured by using an Escalab $250 \mathrm{Xi}$ X-ray photoelectron spectrometer (Thermo Scientific) with nonmonochromatic Al $\mathrm{K} \alpha$ radiation (photon energy, $1486.6 \mathrm{eV})$. Prior to measurements, all of the samples were sputtered by $\mathrm{Ar}^{+}$to remove the contaminant because of the exposure to the air during sample transfer. The binding energy was calibrated by $\mathrm{C} 1 \mathrm{~s}$ peak at $284.8 \mathrm{eV}$ of contamination carbon (Figure S5). The EPR measurements were performed at $100 \mathrm{~K}$ using a Bruker A300 EPR spectrometer, and the samples for each measurement were fixed at $50 \mathrm{mg}$.

Ni dispersion of the catalysts was conducted on a Micromeritics AutoChem 2920 apparatus. $100 \mathrm{mg}$ sample was reduced at $350{ }^{\circ} \mathrm{C}$ for $2 \mathrm{~h}$, then purged with $\mathrm{Ar}$ for $1 \mathrm{~h}$ at $400{ }^{\circ} \mathrm{C}$, and cooled down to $50^{\circ} \mathrm{C}$ in Ar flow. Pulses of $5 \% \mathrm{H}_{2} / \mathrm{Ar}$ were introduced to the catalyst until uptake saturation. The dispersion of Ni was calculated by assuming a H-Ni stoichiometric ratio of 1:1.

$\mathrm{H}_{2}$-TPR experiments were also performed on a Micromeritics AutoChem 2920 apparatus. All the samples were pretreated at $300^{\circ} \mathrm{C}$ for $1 \mathrm{~h}$ under $\mathrm{Ar}$ flow before the experiment. Then, $50 \mathrm{mg}$ sample was heated from 30 to $800{ }^{\circ} \mathrm{C}$ at a rate of $10{ }^{\circ} \mathrm{C} / \mathrm{min}$ in a flow of $5 \% \mathrm{H}_{2} / \mathrm{Ar}$. $\mathrm{H}_{2}$ consumption was monitored by a gas chromatograph with a TCD and was quantified by the reduction area that was calibrated by the reduction of neat $\mathrm{CuO}$.

DRIFTS spectra were collected using a Bruker FTIR spectrometer with a resolution of $4 \mathrm{~cm}^{-1}$. The calcined catalyst was loaded into DRIFTS cell, and then in situ reduced at $350{ }^{\circ} \mathrm{C}$ for $1 \mathrm{~h}$ in $5 \% \mathrm{H}_{2} / \mathrm{Ar}$. The reduced catalyst was cooled to room temperature in Ar flow, and then the background spectrum was collected. 5\% CO/Ar gas was introduced into the DRIFTS cell for CO adsorption. Ar gas was then introduced to the DRIFTS cell to purge CO until the CO adsorption peak intensity stabilized. Eventually, 
the $\mathrm{CO}$ adsorption spectra were recorded.

The $\mathrm{H}_{2}$-TPD experiments were carried out in a fixed-bed quartz reactor. The calcined samples were reduced in $10 \% \mathrm{H}_{2} / \mathrm{Ar}$ at $350{ }^{\circ} \mathrm{C}$ for $2 \mathrm{~h}$, and then cooled down to room temperature. After that treatment, the sample was heated in Ar flow from 30 to $730{ }^{\circ} \mathrm{C}$ at a rate of $10{ }^{\circ} \mathrm{C} \cdot \mathrm{min}^{-1}$, and the transient-mass spectrometer (MS) signals at $\mathrm{m} / \mathrm{z}=2$ $\left(\mathrm{H}_{2}\right)$ were continuously monitored by an online mass spectrometer (Hiden HPR20). 


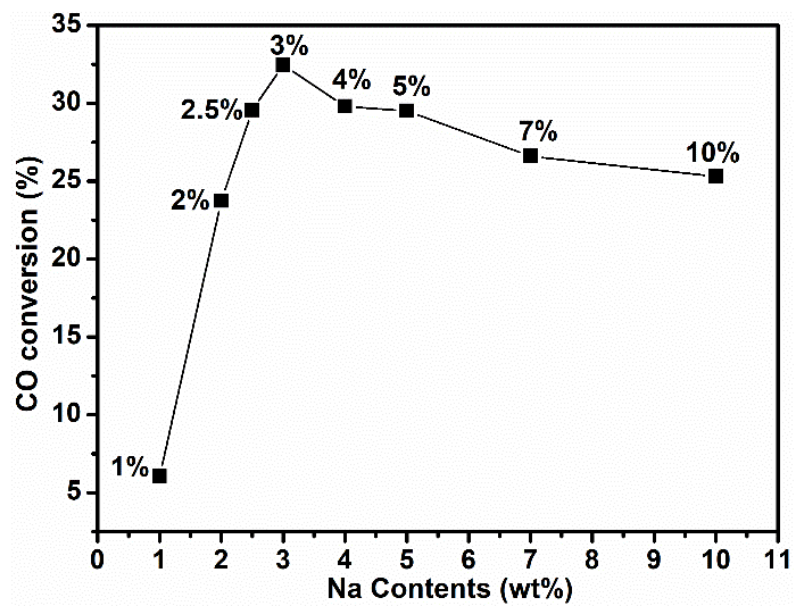

Figure S1. CO conversions at $300^{\circ} \mathrm{C}$ against different $\mathrm{Na}$ contents doped in $\mathrm{Ni} / \mathrm{TiO}_{2}(\mathrm{~A})$.

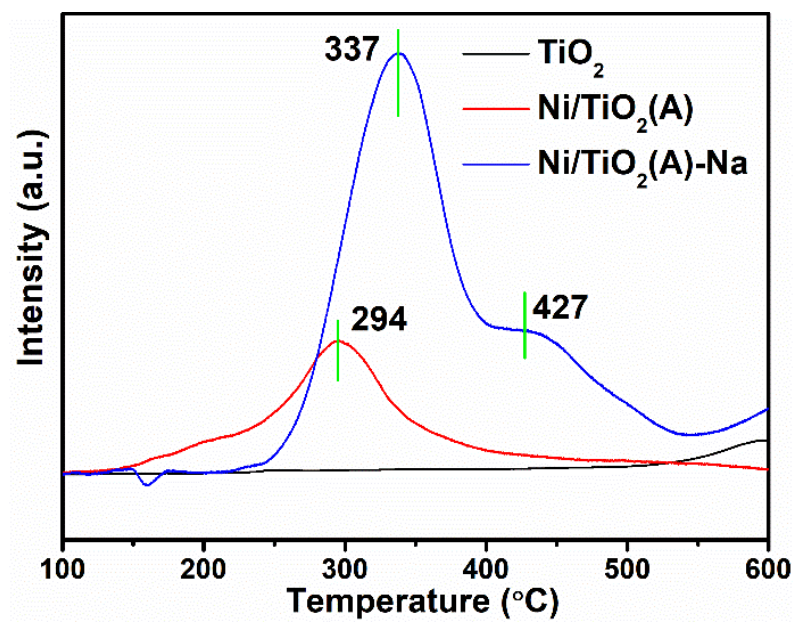

Figure $\mathbf{S 2} . \mathrm{H}_{2}-\mathrm{TPR}$ of the pristine $\mathrm{TiO}_{2}, \mathrm{Ni} / \mathrm{TiO}_{2}(\mathrm{~A})$ and $\mathrm{Ni} / \mathrm{TiO}_{2}(\mathrm{~A})-\mathrm{Na}$ samples. 


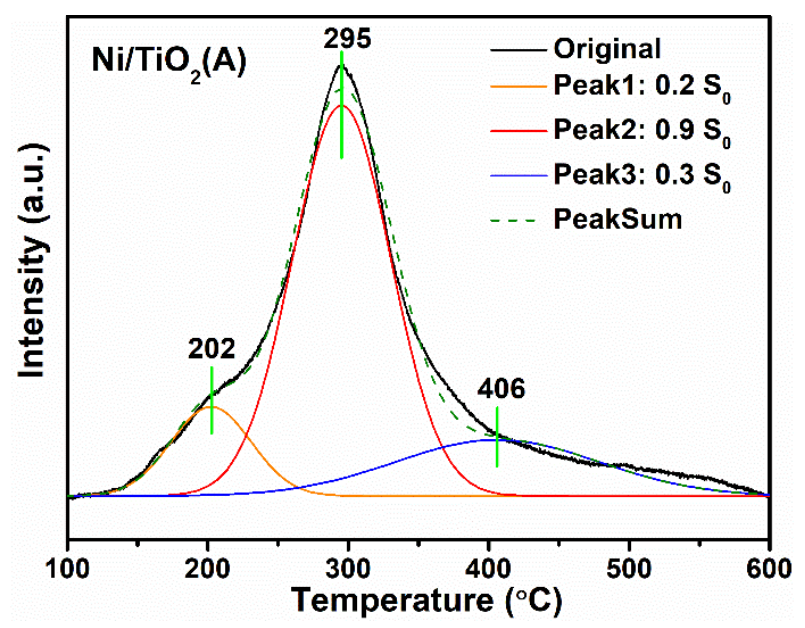

Figure S3. Quantitative analyses of hydrogen consumption of $\mathrm{Ni} / \mathrm{TiO}_{2}(\mathrm{~A}) . \mathrm{S}_{0}$ means the theoretical amount of hydrogen consumption by nickel oxide calculated from the Ni loading of the catalysts.

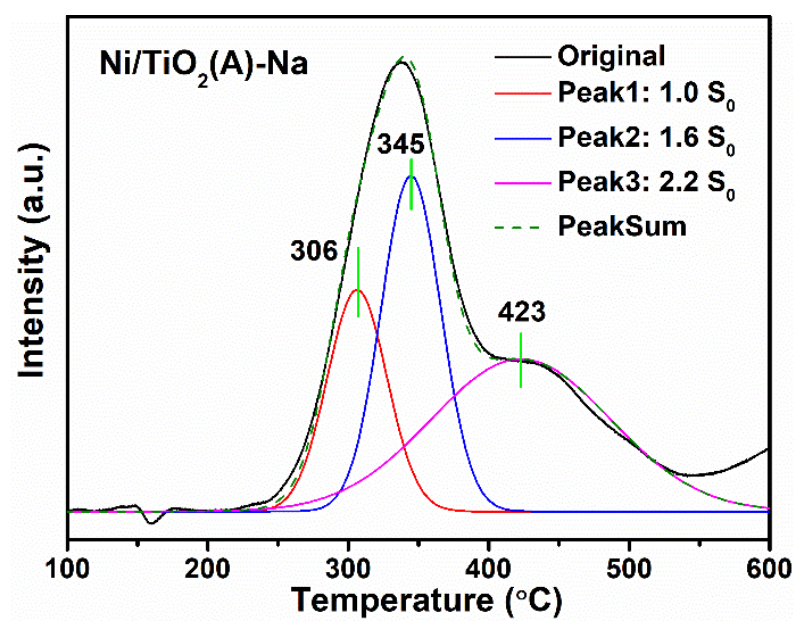

Figure S4. Quantitative analyses of hydrogen consumption of $\mathrm{Ni} / \mathrm{TiO}_{2}(\mathrm{~A})-\mathrm{Na}$. $\mathrm{S}_{0}$ means the theoretical amount of hydrogen consumption by nickel oxide calculated from the Ni loading of the catalysts. 


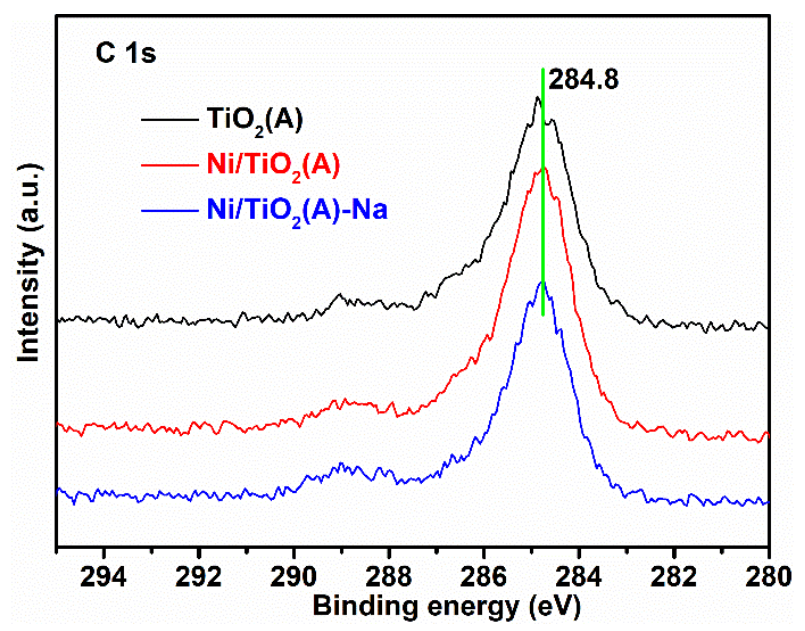

Figure S5. XPS spectra of $\mathrm{C} 1 \mathrm{~s}$ in $\mathrm{TiO}_{2}, \mathrm{Ni} / \mathrm{TiO}_{2}(\mathrm{~A})$ and $\mathrm{Ni} / \mathrm{TiO}_{2}(\mathrm{~A})-\mathrm{Na}$ samples.

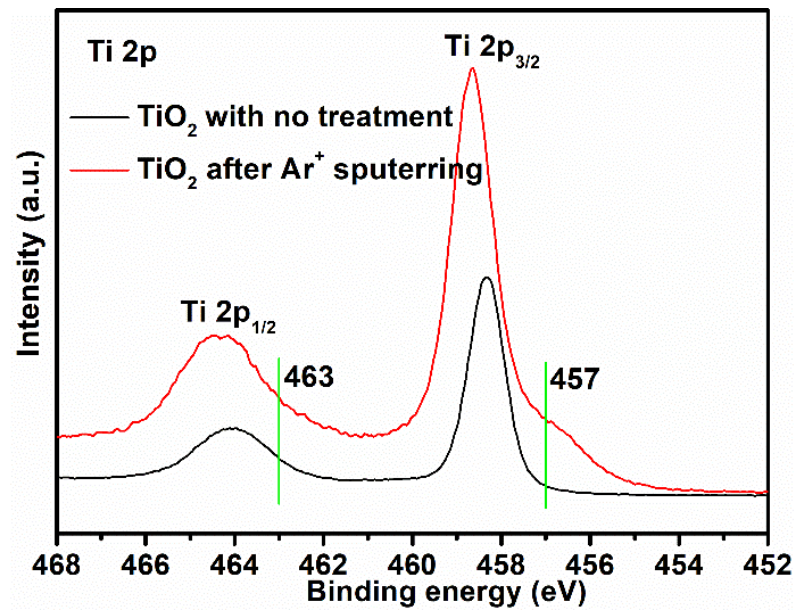

Figure S6. XPS spectra for Ti $2 \mathrm{p}$ of $\mathrm{TiO}_{2}(\mathrm{~A})$ with and without $\mathrm{Ar}^{+}$sputtering.

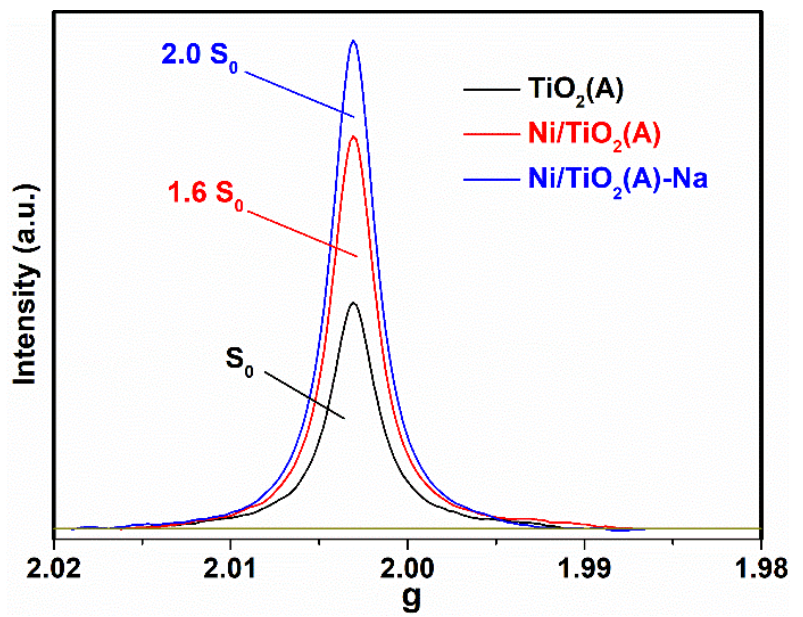

Figure S7. Integral EPR spectra of $\mathrm{TiO}_{2}(\mathrm{~A}), \mathrm{Ni} / \mathrm{TiO}_{2}(\mathrm{~A})$ and $\mathrm{Ni} / \mathrm{TiO}_{2}(\mathrm{~A})-\mathrm{Na}$ catalysts. 


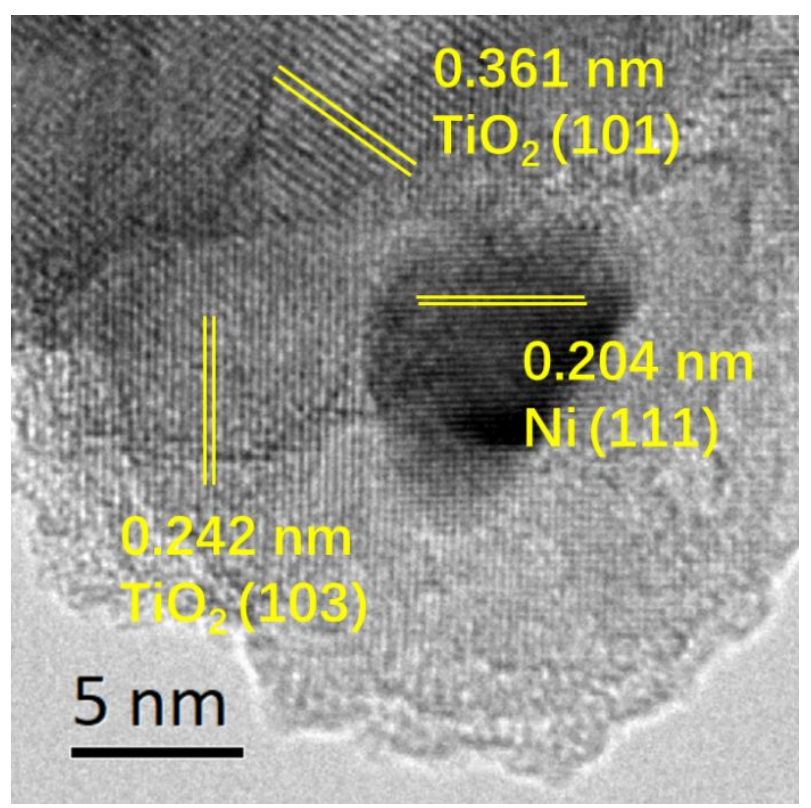

Figure S8. HRTEM image of $\mathrm{Ni} / \mathrm{TiO}_{2}(\mathrm{~A})$ catalyst.

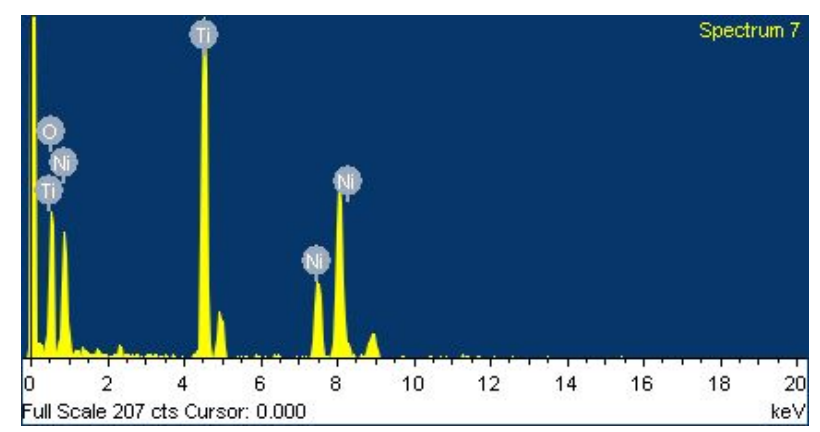

Figure S9. EDS spectrum of Ni particle of $\mathrm{Ni} / \mathrm{TiO}_{2}(\mathrm{~A})$ catalyst in Figure S8. 
Table S1. Element contents of Ni particle of $\mathrm{Ni} / \mathrm{TiO}_{2}(\mathrm{~A})$ catalyst in Figure $\mathrm{S} 8$.

\begin{tabular}{ccc}
\hline Element & Weight \% & Atomic \% \\
O K & 23.79 & 49.40 \\
Ti K & 58.62 & 40.65 \\
Ni K & 17.59 & 9.95 \\
\hline
\end{tabular}

Occasionally, we indeed find a big Ni particle (about $7 \mathrm{~nm}$ ) exposing its (111) surface, whose interplanar spacing is about $0.204 \mathrm{~nm}$ (Figure S8). EDS was applied to make sure it is a Ni particle at the same time (Figure S9), and the element contents are shown in Table S1. The high content of Ni (about 17.6\%) indicates that it is a Ni nanoparticle on the support $\mathrm{TiO}_{2}$.

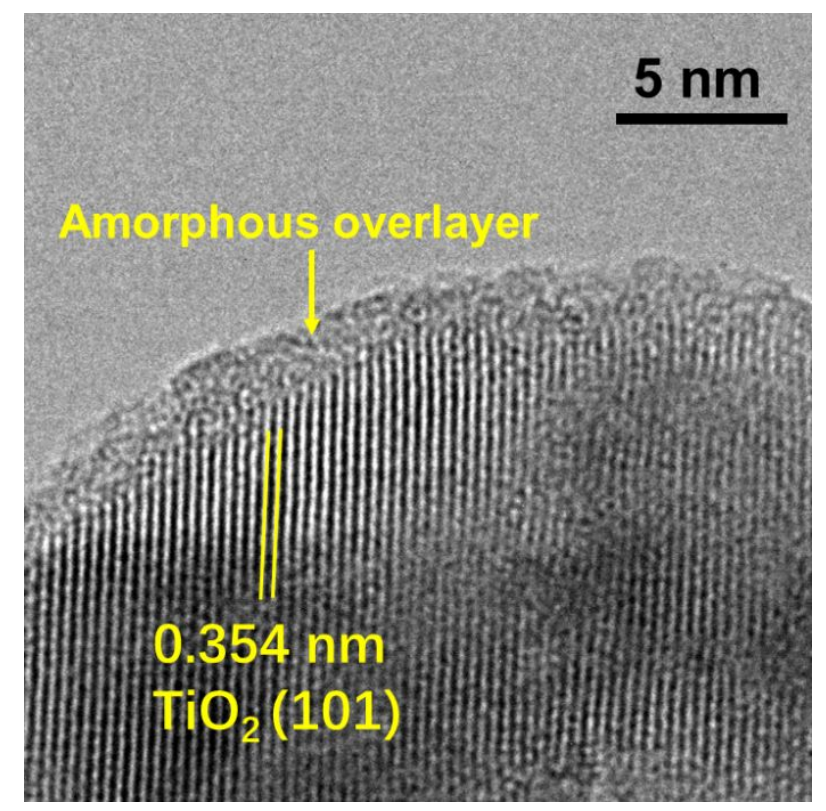

Figure S10. HRTEM image of $\mathrm{Ni} / \mathrm{TiO}_{2}(\mathrm{~A})-\mathrm{Na}$ catalyst. 


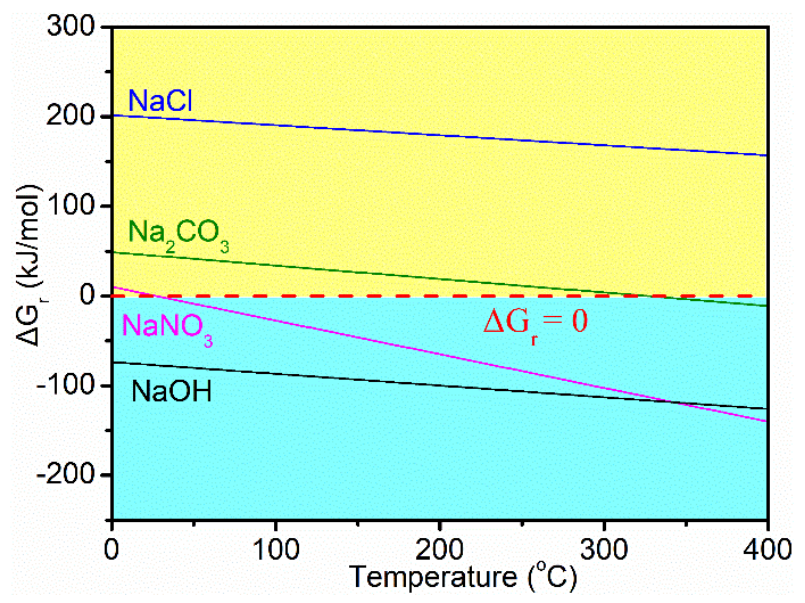

Figure S11. Thermodynamic analyses of the reactions between sodium salts and $\mathrm{TiO}_{2}$ to form sodium titanate.

Table S2. The proposed reactions for $\mathrm{TiO}_{2}$ with sodium salts.

\begin{tabular}{|ll|}
\hline \multicolumn{2}{|c|}{$\mathrm{Na}$ salts } \\
\hline $2 \mathrm{NaOH}+\mathrm{TiO}_{2}=\mathrm{Na}_{2} \mathrm{TiO}_{3}+\mathrm{H}_{2} \mathrm{O}$ & $\mathrm{R} \mathrm{S} 1$ \\
\hline $\mathrm{Na}_{2} \mathrm{CO}_{3}+\mathrm{TiO}_{2}=\mathrm{Na}_{2} \mathrm{TiO}_{3}+\mathrm{CO}_{2}$ & $\mathrm{R} \mathrm{S} 2$ \\
\hline $2 \mathrm{NaNO}_{3}+\mathrm{TiO}_{2}+\mathrm{H}_{2}=\mathrm{Na}_{2} \mathrm{TiO}_{3}+2 \mathrm{NO}_{2}+\mathrm{H}_{2} \mathrm{O}$ & $\mathrm{R} \mathrm{S} 3$ \\
\hline $2 \mathrm{NaCl}+\mathrm{TiO}_{2}+\mathrm{H}_{2} \mathrm{O}=\mathrm{Na}_{2} \mathrm{TiO}_{3}+2 \mathrm{HCl}$ & R S4 \\
\hline
\end{tabular}

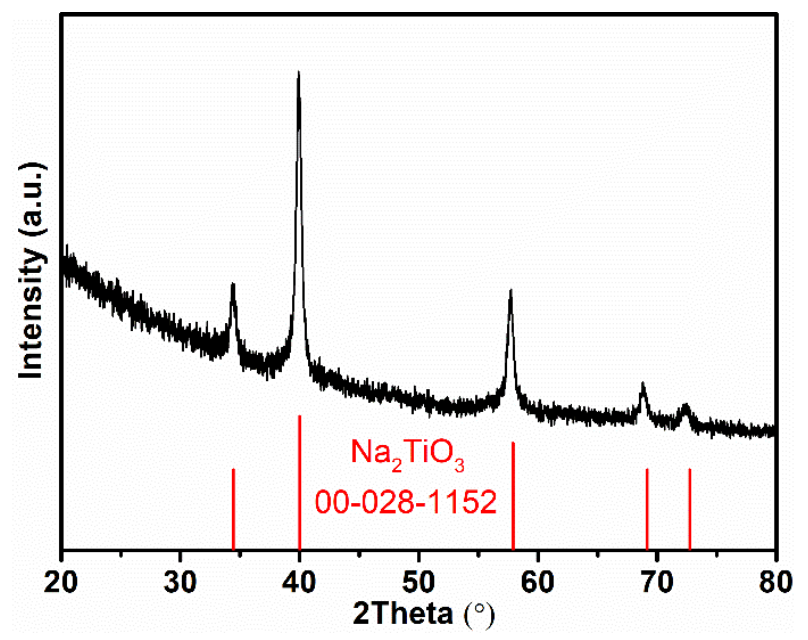

Figure S12. XRD pattern of the sample from the reaction of $\mathrm{NaOH}$ and $\mathrm{TiO}_{2}$ in molar ratio 2:1. 


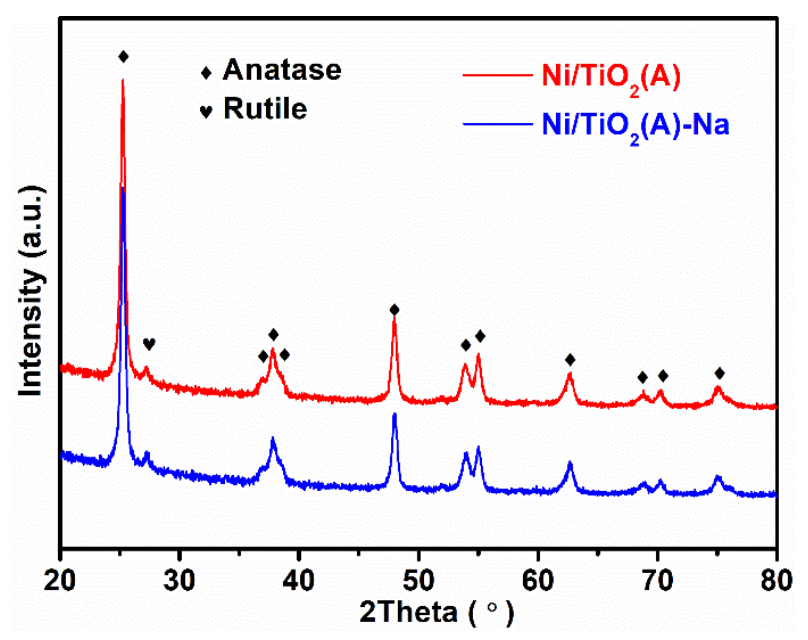

Figure S13. XRD patterns of $\mathrm{Ni} / \mathrm{TiO}_{2}(\mathrm{~A})$ and $\mathrm{Ni} / \mathrm{TiO}_{2}(\mathrm{~A})-\mathrm{Na}$ catalysts.

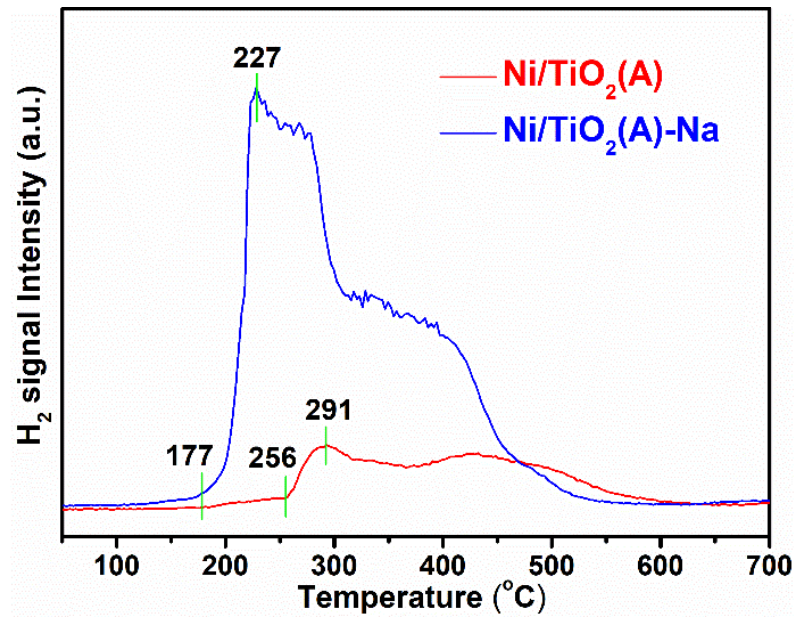

Figure S14. $\mathrm{H}_{2}-\mathrm{TPD}$ profiles of $\mathrm{Ni} / \mathrm{TiO}_{2}(\mathrm{~A})$ and $\mathrm{Ni} / \mathrm{TiO}_{2}(\mathrm{~A})-\mathrm{Na}$ catalysts.

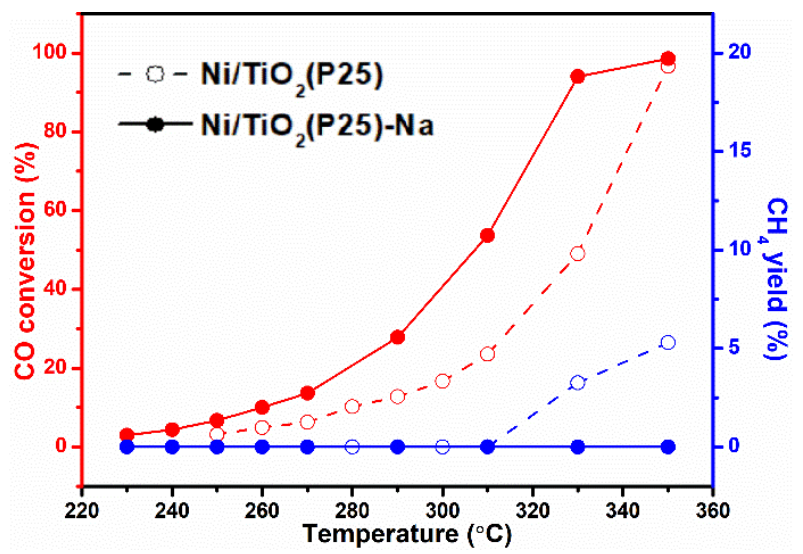

Figure S15. Temperature dependences of catalytic performances over $\mathrm{Ni} / \mathrm{TiO}_{2}(\mathrm{P} 25)$ and $\mathrm{Ni} / \mathrm{TiO}_{2}(\mathrm{P} 25)-\mathrm{Na}$ catalysts, $\mathrm{WHSV}=20000 \mathrm{~mL} \cdot \mathrm{g}^{-1} \cdot \mathrm{h}^{-1}$. 


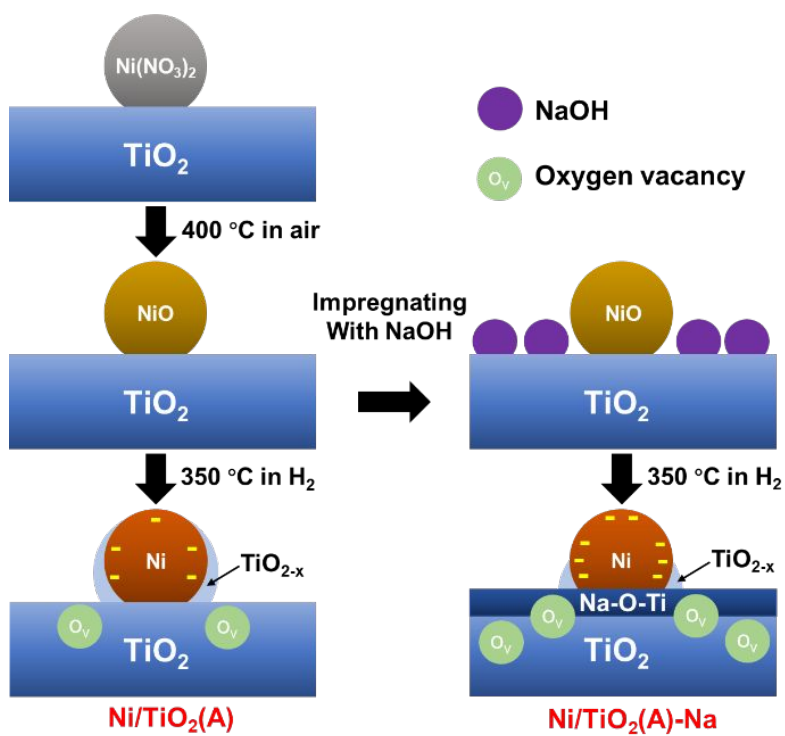

Figure S16. Scheme for the preparation of $\mathrm{Ni} / \mathrm{TiO}_{2}(\mathrm{~A})$ and $\mathrm{Ni} / \mathrm{TiO}_{2}(\mathrm{~A})-\mathrm{Na}$ catalysts. 